\title{
Constraining the temperature history of the past millennium using early instrumental observations
}

\author{
P. Brohan ${ }^{1}$, R. Allan ${ }^{1}$, E. Freeman ${ }^{2}$, D. Wheeler ${ }^{3}$, C. Wilkinson ${ }^{4,5}$, and F. Williamson ${ }^{3,4,5}$ \\ ${ }^{1}$ Met Office Hadley Centre, Exeter, UK \\ ${ }^{2}$ NOAA/STG Inc., USA \\ ${ }^{3}$ Sunderland University, Sunderland, UK \\ ${ }^{4}$ University of East Anglia, Norwich, UK \\ ${ }^{5}$ Catholic University of Valparaiso, Chile \\ Correspondence to: P. Brohan (philip.brohan@metoffice.gov.uk)
}

Received: 4 April 2012 - Published in Clim. Past Discuss.: 4 May 2012

Revised: 17 August 2012 - Accepted: 6 September 2012 - Published: 11 October 2012

\begin{abstract}
The current assessment that twentieth-century global temperature change is unusual in the context of the last thousand years relies on estimates of temperature changes from natural proxies (tree-rings, ice-cores, etc.) and climate model simulations. Confidence in such estimates is limited by difficulties in calibrating the proxies and systematic differences between proxy reconstructions and model simulations. As the difference between the estimates extends into the relatively recent period of the early nineteenth century it is possible to compare them with a reliable instrumental estimate of the temperature change over that period, provided that enough early thermometer observations, covering a wide enough expanse of the world, can be collected.

One organisation which systematically made observations and collected the results was the English East India Company (EEIC), and their archives have been preserved in the British Library. Inspection of those archives revealed 900 log-books of EEIC ships containing daily instrumental measurements of temperature and pressure, and subjective estimates of wind speed and direction, from voyages across the Atlantic and Indian Oceans between 1789 and 1834. Those records have been extracted and digitised, providing 273000 new weather records offering an unprecedentedly detailed view of the weather and climate of the late eighteenth and early nineteenth centuries.

The new thermometer observations demonstrate that the large-scale temperature response to the Tambora eruption and the 1809 eruption was modest (perhaps $0.5^{\circ} \mathrm{C}$ ). This provides an out-of-sample validation for the proxy reconstruc-
\end{abstract}

tions - supporting their use for longer-term climate reconstructions. However, some of the climate model simulations in the CMIP5 ensemble show much larger volcanic effects than this - such simulations are unlikely to be accurate in this respect.

\section{Introduction}

The temperature history of the past millennium provides vital context for predictions of future change, and attributions of recent change to anthropogenic causes (Jones and Mann, 2004). Back to about 1850 large-scale temperature changes are fairly well-known from thermometer measurements (Brohan et al., 2006), but longer time scale reconstructions are based on a variety of natural proxies (tree-rings, ice cores, speleothems, etc.) and have a large uncertainty (Fig. 1).

The proxy reconstructions not only disagree amongst themselves, but they share a reliance on calibration to recent instrumental (thermometer) records. Calibration is a statistical estimate of the scaling factor relating a change in the proxy value (ring width etc.) to a change in temperature, and it is necessary to assume that this scaling factor does not change with time or temperature. Recent years have seen a lot of research into improved calibration techniques, but despite these technical improvements, the uncertainty in the reconstructions remains large (Frank et al., 2010; Jones et al., 2009). 

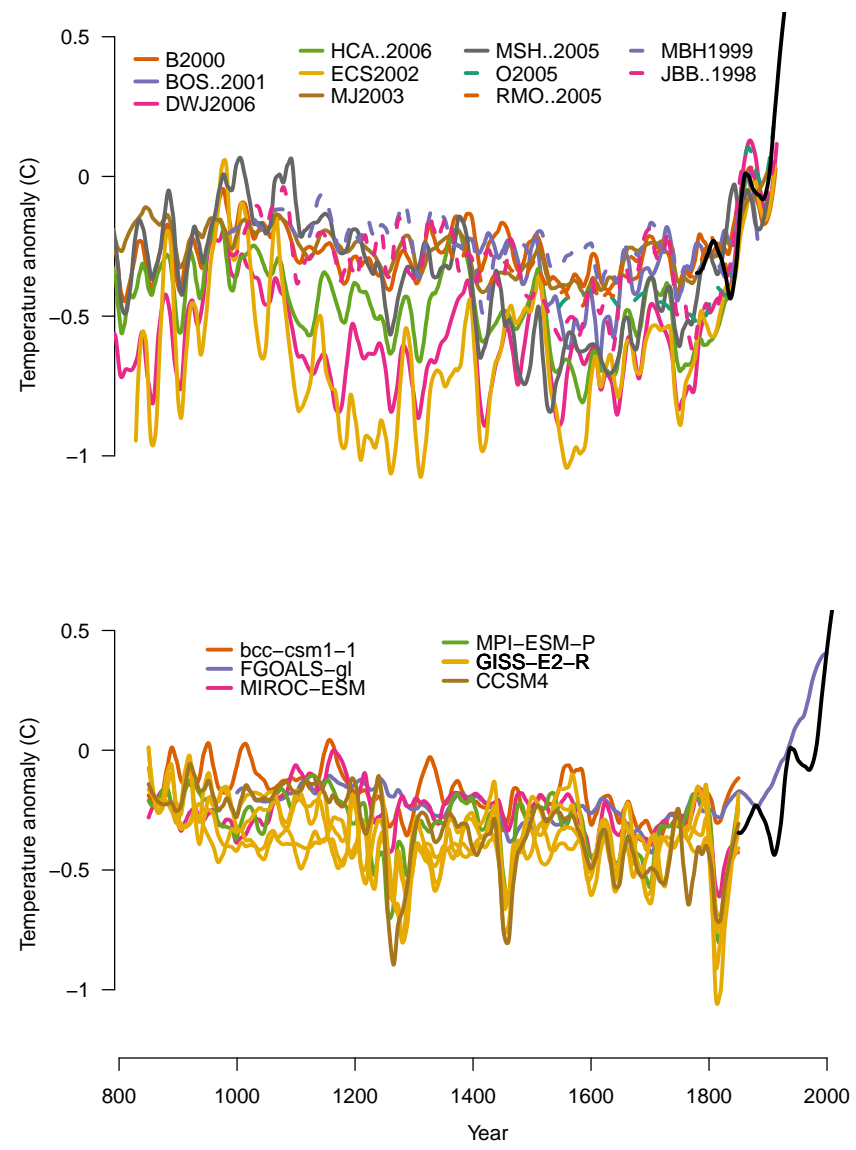

Fig. 1. Northern Hemisphere surface temperature estimates for the last millennium. Upper panel: recent proxy reconstructions (after figure 6.10 of Jansen et al., 2007). Lower panel: GCM simulations from CMIP5 (where possible (MIROC-ESM-P \& GISS-E2-R) these have been corrected for drift by subtracting a linear trend fitted to their unforced parent experiment). In each case the black line shows instrumental observations (Brohan et al., 2006). Data used is listed in Table 1.

An alternative estimate of temperature changes is given by general circulation model (GCM) simulations, and the WCRP Coupled Model Intercomparison Project - Phase 5 (CMIP5 - Taylor et al., 2012) includes an ensemble of state-of-the-art GCM simulations covering the period 8501850 (Fig. 1). Comparison of the GCM simulations with the proxy reconstructions shows systematic differences: the simulations usually have little inter-decadal variability (which would support those proxy reconstructions showing least variance) but often show large responses to volcanic eruptions (which are generally much less pronounced in the proxy reconstructions). This large difference has led to the suggestion that tree-ring based proxy reconstructions systematically underrepresent the effects of large volcanic eruptions (Mann et al., 2012).

Because the main difference between the reconstructions is in their calibration, the spread in centennial and longer
Table 1. Proxy series (top) and modelling groups (bottom) providing data used in Figs. 1 and 9.

\begin{tabular}{ll}
\hline B2000 & Briffa (2000); Briffa et al. (2004) \\
BOS..2001 & Briffa et al. (2001) \\
DWJ2006 & D'Arrigo et al. (2006) \\
HCA..2006 & Hegerl et al. (2006) \\
ECS2002 & Esper et al. (2002); Cook et al. (2004) \\
MJ2003 & Mann and Jones (2003) \\
MSH2005 & Moberg et al. (2005) \\
O2005 & Oerlemans (2005) \\
RMO..2005 & Rutherford et al. (2005) \\
MBH1999 & Mann et al. (1999) \\
JBB.1998 & Jones et al. (1998, 2001) \\
\hline bcc-csm1-1 & Beijing Climate Center, China Meteorological \\
& Administration (Wu et al., 2012) \\
GISS-E2-R & $\begin{array}{l}\text { NASA Goddard Institute for Space Studies } \\
\text { (Schmidt et al., 2006) }\end{array}$ \\
FGOALS-gl & LASG, Institute of Atmospheric Physics, Chi- \\
& nese Academy of Sciences (Zhou et al., 2008) \\
MIROC-ESM & Japan Agency for Marine-Earth Science and \\
& $\begin{array}{l}\text { Technology, Atmosphere and Ocean Research } \\
\text { Institute (The University of Tokyo), and Na- } \\
\text { tional Institute for Environmental Studies }\end{array}$ \\
& (Watanabe et al., 2010) \\
Max Planck Institute for Meteorology \\
MPI-ESM-P & (Raddatz et al., 2007; Marsland et al., 2003) \\
& $\begin{array}{l}\text { National Center for Atmospheric Research } \\
\text { (Gent et al., 2011) }\end{array}$ \\
\hline &
\end{tabular}

time scale temperatures is highly correlated with the spread in shorter time scale variability: reconstructions that have a larger variability over (say) the first few decades of the nineteenth century also show larger variability over the whole reconstruction. So if the reconstructions could be more tightly constrained over a short period, this would reduce the uncertainty over the whole millennium. The early nineteenth century is a strong candidate for such a validation period, as it includes short-term temperature variability of uncertain size associated with large volcanic eruptions (1809 and Tambora in 1815), and there are some thermometer observations for the period, which could potentially be used to quantify the temperature variability much more precisely. Precise information on temperature changes over this period would also resolve a major disagreement between the GCM simulations, which vary greatly in the simulated magnitude of the 1809 and Tambora eruptions.

Accurate instrumental weather observations have been recovered for limited regions going back well before $1800(\mathrm{Ca}-$ muffo and Bertolin, 2011; Alcoforado et al., 2012), so to do this validation, it is merely a matter of recovering enough such observations, covering a large enough area of the Earth, to constrain the large-scale temperature. 


\section{New instrumental weather records for the early nineteenth century}

Amongst the archives in the British Library (BL) in London are some 4000 logbooks from ships in the service of the English East India Company (EEIC); each recording the details and events of a voyage from England to the Indies (usually India, China or both) and back, typically taking the best part of two years. The EEIC received its charter from Elizabeth I in 1600 , and many of its earliest voyages became famous because of their excellent records of new lands; for example that by Henry Middleton to the Moluccas in 1604-6 (Foster, 2010). These early voyages were recorded in diaries; logbooks - formally prepared documents of a standard format - did not begin to appear until the 1650s. Their preparation was part of an officer's duties until the gradual expansion of the Company in the 1830s into a quasi-military and political body responsible for overseeing British interests in India and beyond. Those archived in the BL, therefore, extend from the 1600s through to the 1830s, and are well-known to historians (Farrington, 1999). They document social conditions, discipline, medicine and health, the trade and transport of goods, people and passengers. They touch on first contact with new lands and peoples, convey colonial attitudes and cultures, and describe long lost coastal towns and villages. Many even contain detailed drawings of coastlines, ships, mammals, birds and sea creatures.

Ship's logbooks are also valuable sources of historical climate data (Chenoweth, 1996; Wheeler et al., 2006; Brohan et al., 2009, 2010), and the EEIC logbooks include daily records of the weather along the routes taken by the ships: they cover large parts of the Atlantic and Indian Oceans, and include the occasional foray into the Pacific. All the logbooks contain wind speed and direction records, as this was vital information for early navigators, but the later logs, starting in about 1790, are even more valuable, as some of them contain daily thermometer and barometer observations as well as the wind reports. The principal instigator of the addition of instrumental observations was Alexander Dalrymple - the Company's, and later the Royal Navy's, first hydrographer. Dalrymple was both an explorer and an enthusiastic scientist, and, as hydrographer, he was responsible for ensuring that the EEIC ships could transport goods to and from England as quickly as possible and at minimum risk of loss. With this in mind, he equipped the East Indiaman Grenville with a set of meteorological instruments for her voyage in 1775 under Captain Burnet Abercrombie (Dalrymple, 1778), and set a pattern to be later adopted by officers on all EEIC ships.

It is the routine inclusion of regular instrumental weather observations that distinguishes the EEIC logbooks from their contemporaries, such as the Royal Navy and the Hudson's Bay Company (which did not routinely make such records until many years later). The EEIC logbook records offer a potential source of detailed information on climate change and variability over a large area of tropical and sub-tropical ocean for the late eighteenth and early nineteenth century a time and region where other observations are almost completely missing. About $10 \%$ of these logbook observations have been examined in previous studies (Chenoweth, 1996, 2000; Farrington et al., 1998), but most of them have never been digitised or examined, and none have made it into the standard climate datasets for widespread use.

\section{Digitisation of the weather records}

The BL's EEIC logbook collection has been catalogued (Farrington, 1999), but that catalogue, though extensive, does not distinguish those logbooks that contain instrumental data. So research was undertaken in the BL archives to produce a catalogue detailing exactly which logs contain instrumental observations; whether the observations are of pressure, air or sea surface temperature; the name of the ship; the year of its voyage; and the ship's route with dates. It also includes additional information such as how frequently the readings were taken, and whether any unusual weather events took place. Many of the logbooks dating from 1790 or later contained some instrumental observations, but not every log contained observations, and on occasion observational records were sporadic.

Using this catalogue, the 891 logbooks including consistent instrumental records were selected for digitisation: the earliest that of the Melville Castle, starting in February 1789; and the last that of the Sherborne, finishing in August 1834. Figure 2 shows a typical example, logbook records for one day from EIC ship Carmarthen.

That logbook records a voyage from London to Bombay and back to the UK, through the Atlantic and Indian Oceans, and round the Cape of Good Hope. The voyage took 20 months (May 1810 to January 1812); records were only made on days when the ship was at sea, but even so the logbook includes 372 such daily records.

Digitising each day's observations from all 891 logbooks proved to be a major undertaking. To make it possible to work on the logbooks outside the BL, the books were photographed. This produced about 140000 digital images, each showing one page. Most pages contained two day's records on a standard pre-printed form (Fig. 2 shows the top half of one page) though, in rare cases, variant form types were used that only contained one day's records; also hand-drawn forms were occasionally used - presumably to make up a shortfall in printed forms. These images were indexed and stored in the electronic media archive of the US Climate Database Modernisation Program (CDMP), managed from the National Oceanic and Atmospheric administration's (NOAA) National Climatic Data Center (NCDC).

CDMP also managed the transcription of the weather observations from the images. The data to be transcribed were selected - these are the highlighted sections in Fig. 2 - and 


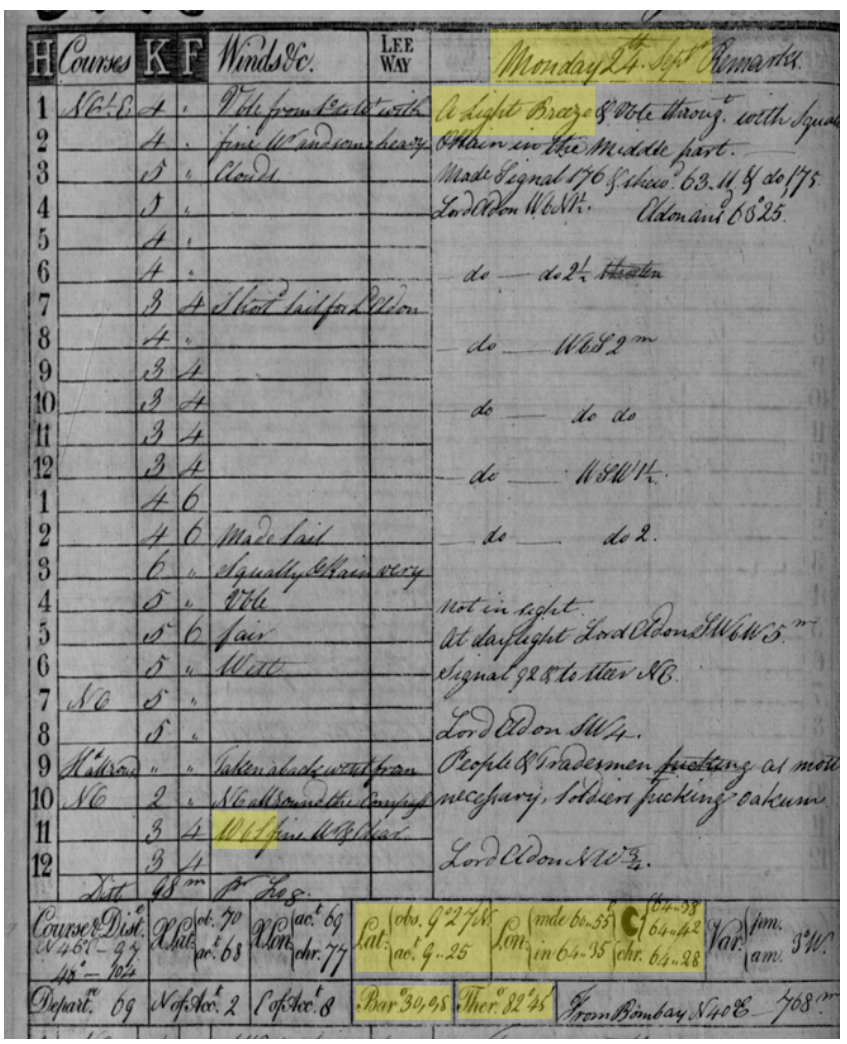

Fig. 2. Logbook of EIC ship Carmarthen for 24 September 1810. Ship's days run from noon to noon $12 \mathrm{~h}$ ahead of the civil day, so this covers the afternoon of the 23rd and the morning of the 24th. For each hour there is space to enter the ship's course, its speed (in Knots and Fathoms), and the wind direction. To the right of this table is a section for general remarks (which almost always includes reference to the wind speed); and at the bottom is a table of summary data for the day. The elements digitised are highlighted in yellow. From top to bottom they are as follows: the date (24 September); the wind force (a light breeze - Beaufort force 2); the wind direction (West by South $-258.75^{\circ}$ magnetic); the noon position ( 9 degrees 27 min North, 64 degrees 28 min East); the barometric pressure (30.05 inches of mercury); and the air temperature (82 degrees $45 \min -82.75^{\circ}$ Fahrenheit)

staff were trained to read and key the specified elements. A detailed set of instructions was prepared for the keying operators to ensure that the data was transcribed into a uniform format. Budget constraints limited transcription to the noon observations of air temperature, barometric pressure, and location; the wind direction and force closest to noon, and all details of the state of the weather and sea. Each element was double keyed to a give a minimum transcription accuracy of $99 \%$.

For the most part the logbooks recorded elements to a basic standard that can easily be understood today. However, the age of the documents made the transcription unusually challenging: the handwriting is not easy to read and contains frequent and variable abbreviations, and the document format is not entirely regular, so judgement was often required in identifying the elements to be transcribed. Values were sometimes recorded in unconventional methods (e.g. complex fractions or the use of dashes (-) to represent the number zero), and sometimes positioned on the wrong part of the form. Every logbook was pre-screened to notify the keying operators of any strange and unusual recording methods or deviations from the most common recording practises, and the keying operators were vigilant in identifying irregularities. Unusual entries often required a full review of the logbook to determine how the observer was recording the questionable element and if they were consistent throughout with their recordings. Once the logbook was thoroughly inspected, an educated decision was made on how to transcribe the values to the common format outlined in the keying instructions. Once a logbook had been keyed in its entirety, it was then quality controlled by CDMP and distributed for further format conversions and analysis. In all 272852 daily records were transcribed.

To be useful to the community of climate and other researchers who use historical marine observations, each record must be converted into the International Maritime Meteorological Archive format (Woodruff, 2007). In most respects such conversion is straightforward - conversion of latitude from degrees-minutes-seconds to decimal degrees, and of temperatures from Fahrenheit into Celsius. Conversion of pressure measurements is slightly more complicated, as not only must the measurements be converted from inches of mercury to hectopascals, but corrections may be applied for systematic biases in the method of measurement (Sect. 3.2.2). Conversion of wind direction from 32 or 64point compass directions to degrees east is also straightforward, but the wind speed must be converted to $\mathrm{ms}^{-1}$ from verbal descriptions such as light gale or moderate monsoon (Sect. 3.2.3). Temperature, pressure, and wind records are further discussed below.

As well as the units conversion and adjustment, the opportunity was taken to apply some basic quality control to the ship positions. In many cases the hemisphere flags (E/W or $\mathrm{N} / \mathrm{S}$ ) attached to position observations were missing or obviously wrong, occasionally obvious errors would appear in latitudes and longitudes as well. All these problems can be seen plainly in a plot of the course of the ship and such erroneous values, when found, were corrected if the correction was obvious, and set to missing otherwise.

The IMMA format allows attachments, and the original version of each record is attached to each IMMA record, so that the un-converted and un-corrected data can be recovered if necessary. All the IMMA records are provided as Supplement.

\subsection{Ship routes and observational coverage}

A sailing ship travelling between England and the Indies, before the opening of the Suez canal in 1869, had to follow 


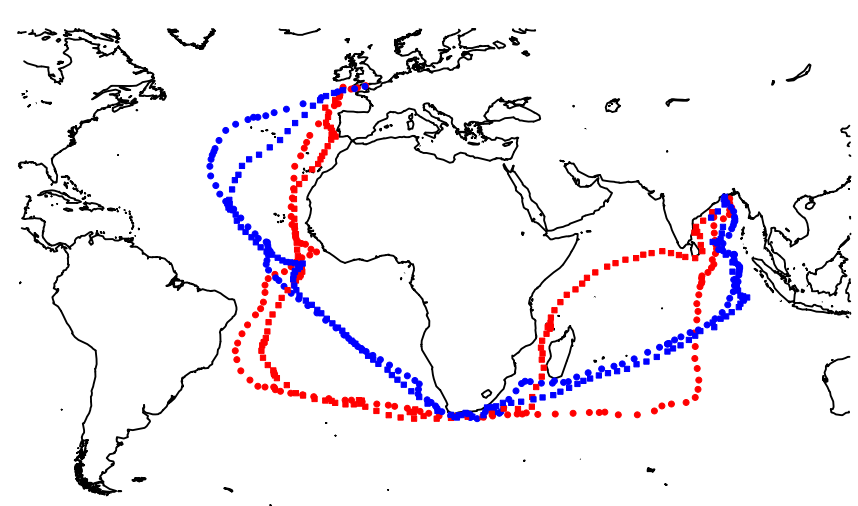

Fig. 3. Daily positions on the outward (red) and return (blue) voyages of the Astel in 1812-1813 (squares) and Thomas Grenville in 1827-1828 (circles).

a route constrained by the global wind fields: the prevailing winds close to the Equator are the easterly trades, so sailing to the East from England meant travelling southwest through the Atlantic down to the latitudes of the Southern Hemisphere westerlies, and using those winds to make the necessary easting. Once in the Indian Ocean the ships could either sail up through the Mozambique Channel (between Madagascar and the continent of Africa) and use the southwest monsoon to carry them over to India, or make all their Easting in the strong westerly winds around $35-40^{\circ}$ south and then sail directly north to their destination. Both choices remained popular throughout the period: the Mozambique Channel could only be used if arriving in boreal summer (when the southwest monsoon blows in the northern Indian Ocean) the alternative route was used throughout the year. Figure 3 shows examples of both routes.

The route back was simpler - a direct route round the Cape using the easterly trades, north-west into the mid-Atlantic and then back to England with the Northern Hemisphere westerlies.

Figure 4 shows the coverage of the observations from all 891 logs. The observations are strongly concentrated along the standard routes, but with enough variation to explore a large area of the Atlantic and Indian Oceans - occasionally ships do take radically different routes - visiting the Red sea and Persian Gulf, or looping through the South Pacific on the way to China. The records are fairly evenly distributed through time, with at least 30 ships contributing in every year between 1794 and 1833.

\subsection{Temperature, pressure and wind}

The logbooks contain instrumental observations of air pressure and temperature, and qualitative descriptions of wind speed. The details of how the measurements were made are not known, and we should expect some biases even in the instrumental observations, caused by limitations in the instruments used and the observational protocols. The model
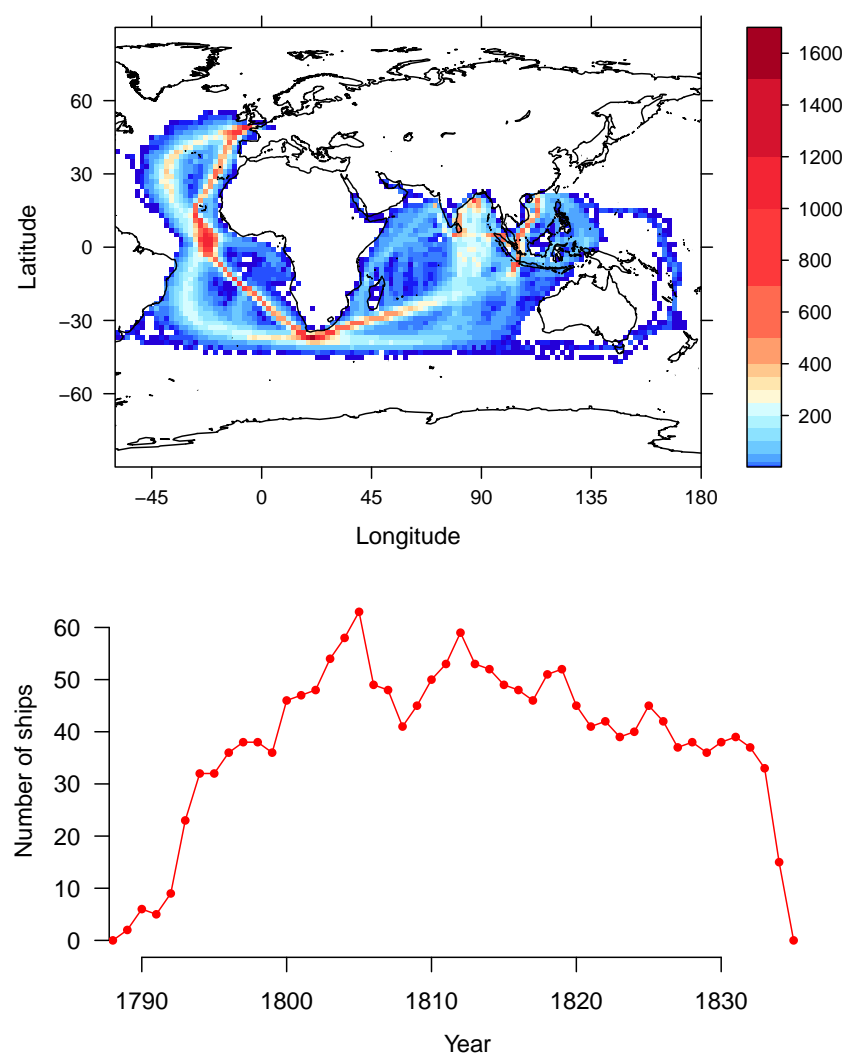

Fig. 4. Geographical coverage of the observations. Upper panel: total number of observations in each $2 \times 2$ degree square. Lower panel: number of ships providing observations in each year.

and make of instruments used on board the EEIC vessels is rarely recorded within the logbooks, and in most cases no record has been found indicating the manufacturer or type of instrument used. Dalrymple's 1775 voyages used barometers and thermometers of Nairne and Blunt manufacture (Dalrymple, 1778) but it is known from some of the more assiduously maintained logbooks that barometers of different manufacture were also used, such as Dolland, Barraud, Troughton, and Gilbert. On occasion more than one barometer was in use (e.g. Dolland, Barraud and Troughton on board the Thomas Coutts voyage of 1817-1819), and multiple thermometers are also occasionaly seen (e.g. Gilbert and Blunt manufactures on board the Neptune voyage of 1814-1815). It is likely that a diverse range of instruments was used across the EEIC fleet.

The vast majority of the temperature and pressure observations were made at noon (a handful of logbooks record morning and afternoon observations on the same day); the location of the instruments is not known for certain, but it is likely that the thermometer and barometer were kept together in the captain's quarters and adjacent gallery at the stern of the vessel - Dalrymple's report includes the following "this thermometer belonged to Mr. Russell, and hung in the open air in the balcony" (Dalrymple, 1778). 

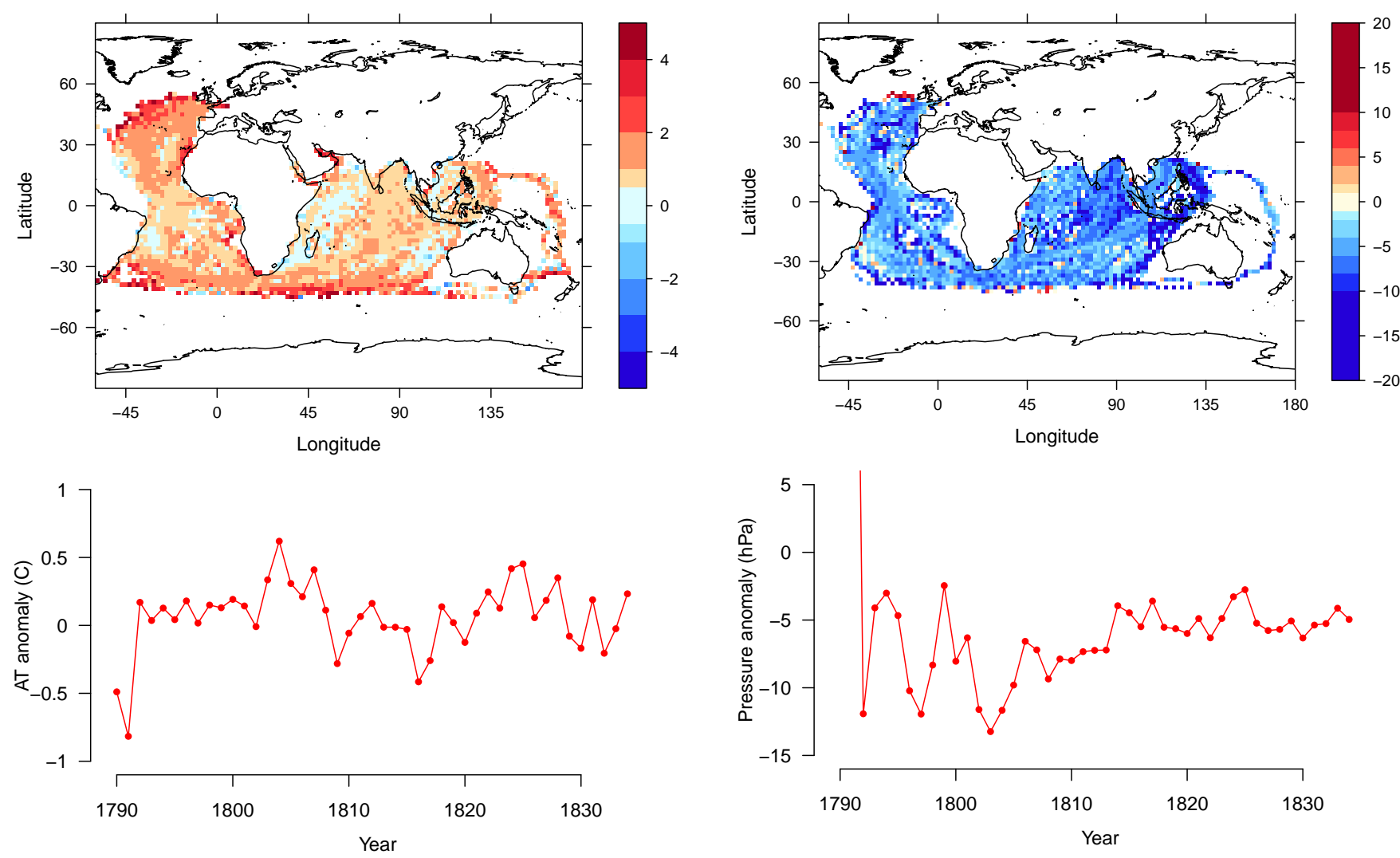

Fig. 5. Air temperature (AT) anomalies $\left({ }^{\circ} \mathrm{C}\right)$ : observations minus an air-temperature climatology for 1961-1990 (Rayner et al., 2003). Upper panel: truncated mean AT anomaly in each $2 \times 2$ degree square. Lower panel: truncated mean AT anomaly in each year. Note that the observed temperatures are not bias-adjusted.

\subsubsection{Temperature}

The temperatures are recorded in degrees Fahrenheit: usually to a precision of 1 degree but sometimes to a quarter or a tenth of a degree. In some instances thermometer values were recorded in the format of degrees and seconds (e.g. $82^{\circ} 45^{\prime}$, representing $82.75^{\circ} \mathrm{F}$, as seen in Fig. 2), similar to the typical format for latitude or longitude. As the observations predate the development of the modern Stevenson-type screen, the major difficulty in comparing them to modern observations will be their exposure - the details of how the thermometer was screened from solar radiation. It is likely that the thermometers were less well screened than the modern standard, and also contaminated by ship heating (Chenoweth, 2000; Berry and Kent, 2005). They will therefore be biased warm, and the bias will be larger in regions where the surface solar radiation is large. Figure 5 shows the distribution of the temperature anomalies (difference from recent values).

The temperatures are consistently warmer than their recent equivalents, but the difference is much more likely to be a result of exposure bias than an indication that surface temperatures were warmer in 1789-1834 than in 1961-1990.

Fig. 6. Air pressure (AP) anomalies from mercury barometers (hPa): observations minus a sea-level pressure climatology for 1961-1990 (Allan and Ansell, 2006). Upper panel: mean AP anomaly in each $2 \times 2$ degree square. Lower panel: mean AP anomaly in each year.

The mean temperature changes little over the period of the observations, with modest falls in 1809 and 1816 - almost certainly a consequences of the two large tropical volcanic eruptions in the period.

\subsubsection{Pressure}

The pressures were recorded in inches of mercury, usually to a decimal precision of $1 / 100$ of an inch, but occasionally as a fraction (e.g. $297 / 8^{\prime \prime}$ ). The pressures have been corrected for gravity (using the observed ship latitude) and for temperature (using the associated air temperature where available no barometer attached temperatures were recorded). Figure 6 shows the distribution of the pressure anomalies (difference from recent values).

The pressures are systematically and consistently about $5 \mathrm{hPa}$ ( 0.15 inches) below their recent equivalents. This bias has been observed before in pre-1855 marine observations (Ansell et al., 2006; Brohan et al., 2010) and the cause is still unknown. It is unlikely to be an effect of gravity or temperature correction because it does not vary with temperature or latitude, and it seems equally unlikely to be an artifact of 


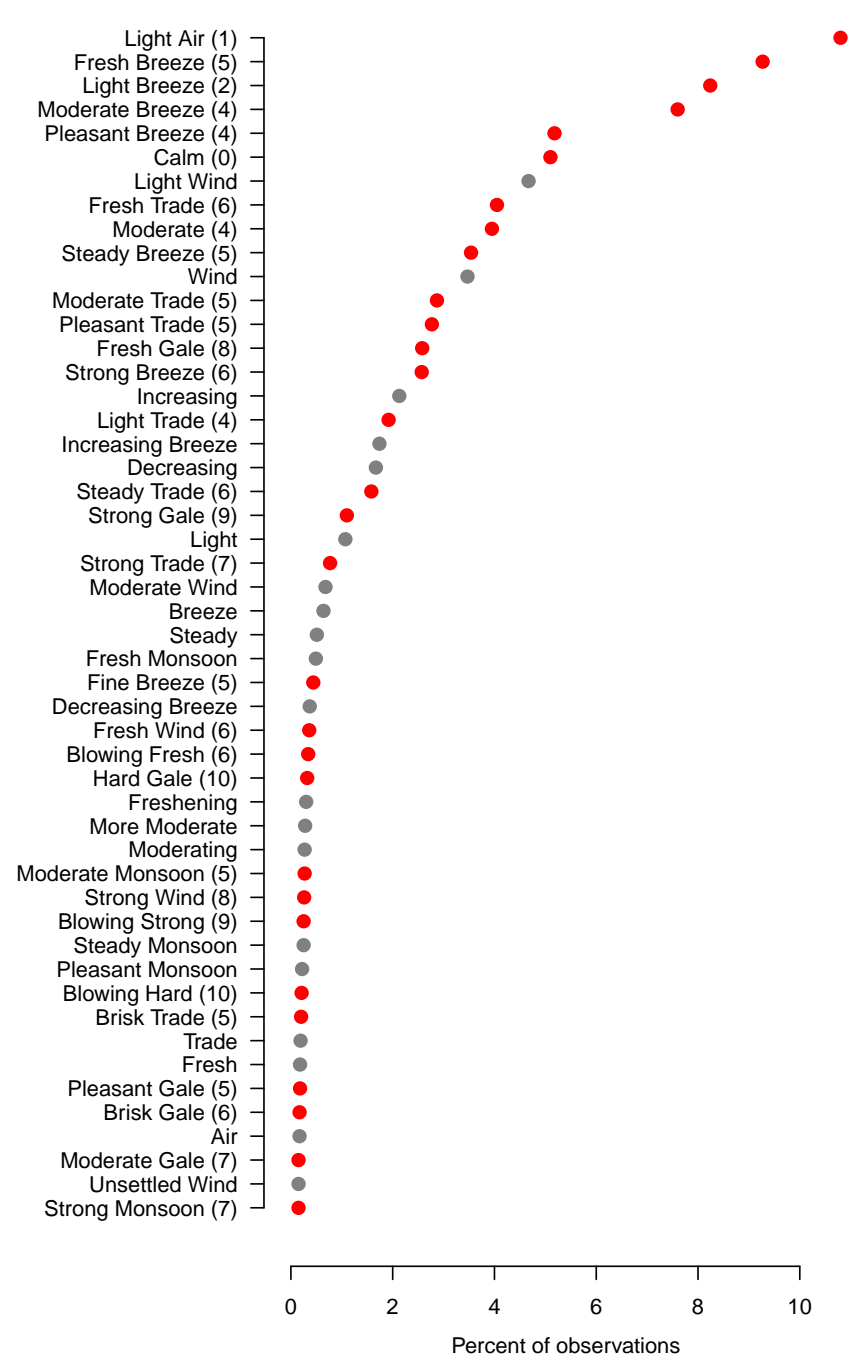

Fig. 7. The most common wind-force descriptors in the logs. Red points mark descriptors that can be converted to a Beaufort force using the CLIWOC dictionary (the Beaufort category is given in brackets after the descriptor in these cases). Grey points are terms which can't be converted.

the movement of the ship as it appears equally in stormy and calm regions.

In 1818, Alexander Adie patented the sympiesometer, a mercury-less marine barometer containing coloured almond oil and hydrogen gas (Middleton, 1964). Several of the later EEIC voyages carried a sympiesometer, either in tandem with the mercury barometer or as a standalone pressure gauge: 31 of the 893 digitized logbooks have records from sympiesometers. Of those $31 \operatorname{logs}, 30$ also contained records from a mercury barometer, and in some cases simultaneous observations from both instruments were recorded.

There are large and systematic differences between the sympiesometer and barometer measurements. The sympiesometer was designed to be portable and to respond rapidly to pressure changes, rather than for accuracy and stability;
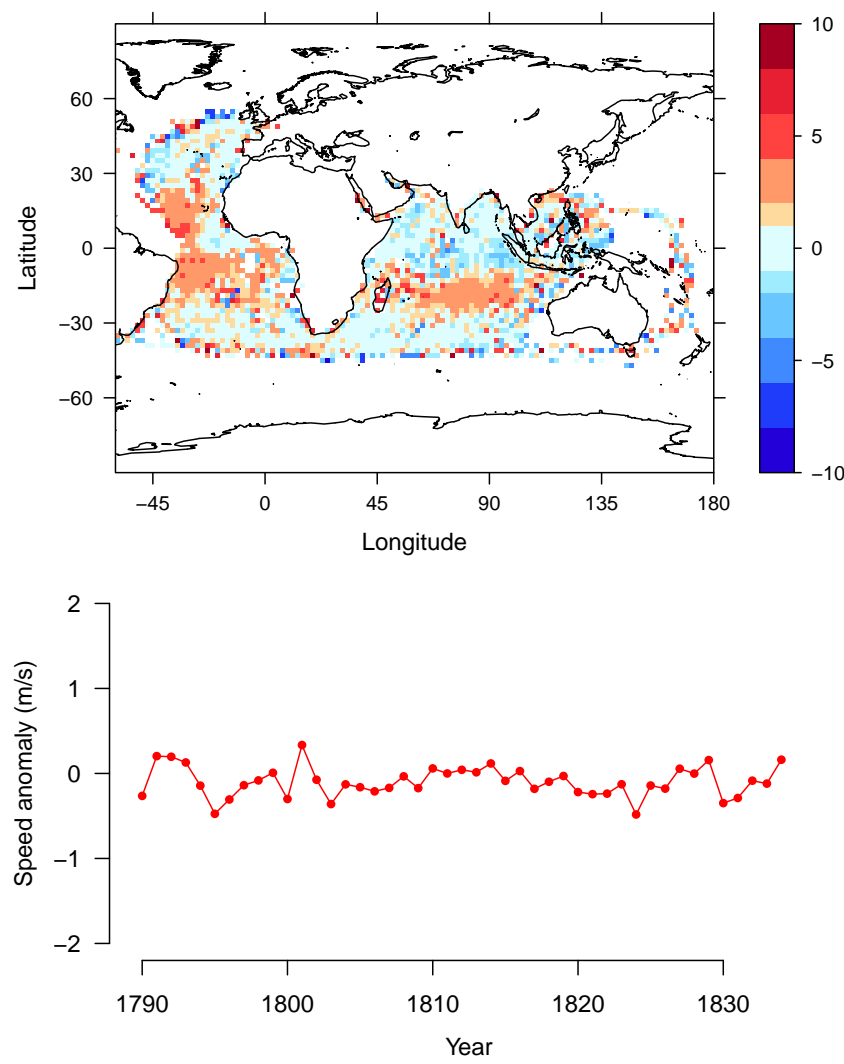

Fig. 8. Wind-speed (WS) anomalies $\left(\mathrm{m} \mathrm{s}^{-1}\right)$ : observations minus a wind-speed climatology for 1961-1990 from the ERA-40 reanalysis (Uppala et al., 2005). Upper panel: truncated mean WS anomaly in each $2 \times 2$ degree square. Lower panel: truncated mean WS anomaly in each year.

and time series of sympiesometer measurements (not shown) often show large drifts in pressure readings over a voyage. So the indications are that sympiesometer records will need close attention to calibration and correction in order to be useful for historical reconstructions.

The pressure observations included in the attached IMMA records are all believed to be from mercury barometers, but it is possible that in some of the later voyages the pressure observations are actually from a sympiesometer. That is, a sympiesometer has been used in place of the usual mercury barometer but the substitution is not mentioned in the logbook.

\subsubsection{Wind speed}

The wind-speed observations in the logbooks are, as is usual at sea, subjective assessments based on the sails carried and the state of the sea. The vocabulary of such assessments was not formally standardised until the 1830s, when Sir Francis Beaufort succeeded in introducing an official scale, but, even in this pre Beaufort-scale age, sailors were very consistent in their description of the winds, and it is possible to make 


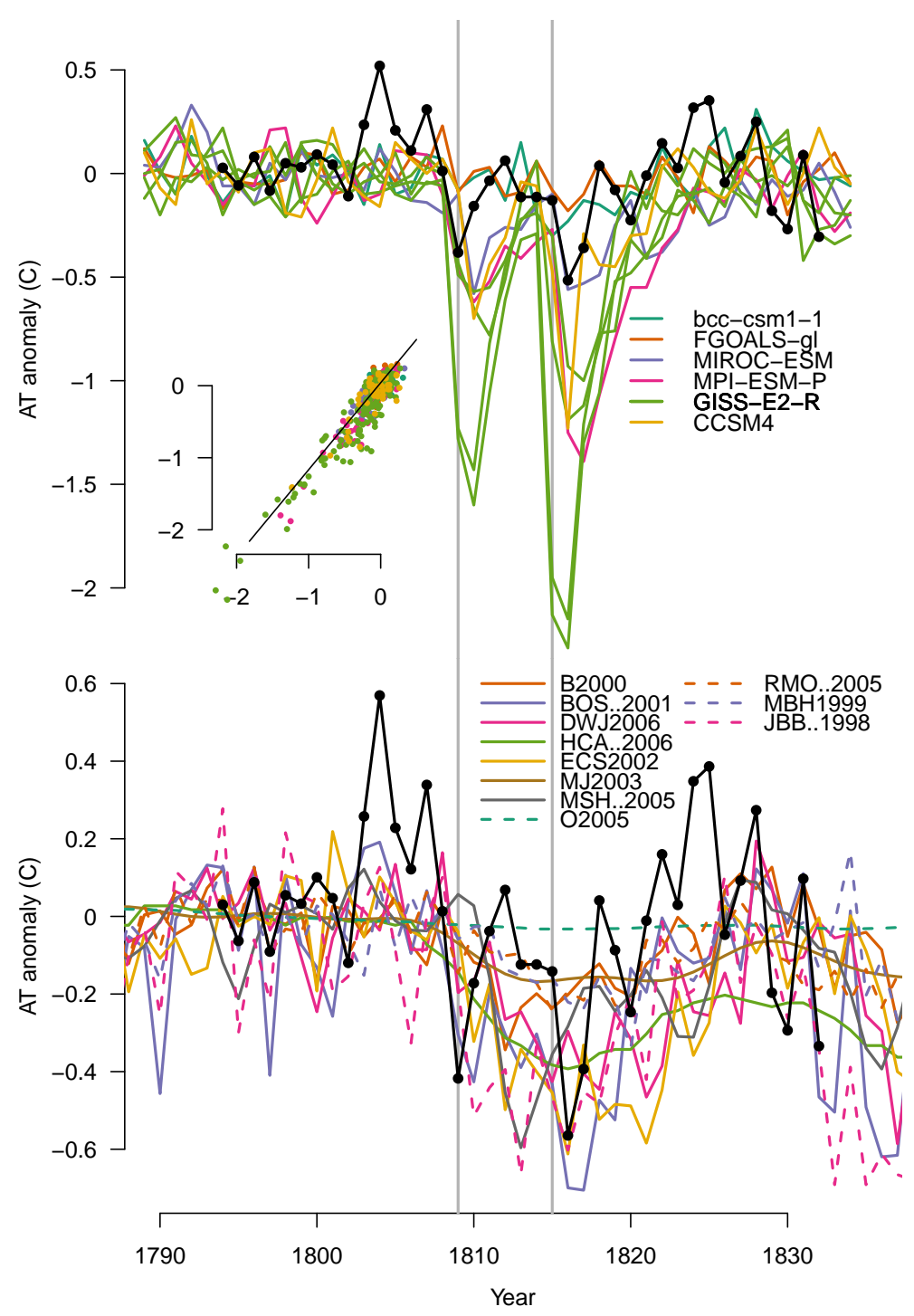

Fig. 9. Comparison of observed, simulated, and proxy-derived large-scale near-surface temperature variability over the early nineteenth century. Upper panel: tropical (observations coverage) marine temperatures from observations (black) and the CMIP5 simulations. Lower panel: Northern Hemisphere temperatures from observations (black) and proxy reconstructions. Inset: relationship between observations coverage $(x)$ and Northern Hemisphere $(y)$ temperature in the simulations, with best fit line (slope 1.2). All series normalised to have mean zero over 1795-1805. The grey vertical lines mark the dates of two large volcanic eruptions (1809 and 1815). Data used is listed in Table 1.

quantitative estimates of the wind speed from the language in the logs (CLIWOC, 2003). Figure 7 shows the most frequent wind-force terms used and their Beaufort equivalents where available.

About $80 \%$ of the terms encountered can be converted to Beaufort forces, and so to $10-\mathrm{m}$ wind speeds in $\mathrm{m} \mathrm{s}^{-1}$. Figure 8 shows the distribution of the inferred wind-speed anomalies (difference from recent values).

The notable feature of Fig. 8 is the large anomalies in the trade-wind regions. It is possible that the trade winds were stronger around 1800, but as no equivalent anomaly appears in the pressure fields it is more likely that the CLIWOC dictionary is slightly miscalibrated in those regions (stronger trades imply a stronger sub-tropical high or a deeper equatorial low).

Although all the pressure and temperature observations in the selected logbooks were digitised, budget constraints meant that not all of the much more numerous and various wind observations were. There are also wind observations in the more than 3000 logbooks in the BL archive that were not examined in this study (because they had no instrumental pressure or temperature observations). So much more information on wind fields is still potentially available in the BL EEIC logbook archive. If extracted in a future project, these records would provide information on sub-daily weather variability back into the 17 th century. 
Table 2. Ships from which observations were taken (1 of 2 - starting dates 1789 to 1803 ).

\begin{tabular}{|c|c|}
\hline Ship Name & Years of operation \\
\hline Melville Castle & $1789-1790,1792-1793,1796-1802$ \\
\hline Rose (2) & 1789-1790,1799-1800 \\
\hline Barwell (1) & $1790-1791,1795-1796$ \\
\hline Belvedere & $1790-1791$ \\
\hline Earl Of Abergavenny (2) & $1790,1797-1800$ \\
\hline Marquis Of Lansdown & $1790-1791,1793-1800$ \\
\hline Ocean (1) & $1791-1797$ \\
\hline Bridgewater (3) & $1791-1793,1796-1797$ \\
\hline Lascelles & $1792-1796$ \\
\hline Middlesex (2) & $1792-1795$ \\
\hline Royal Admiral (1) & $1792-1796$ \\
\hline Swallow (3) & $1792-1794$ \\
\hline Ganges (1) & $1792-1795$ \\
\hline General Goddard & $1792-1793$ \\
\hline Pigot (2) & $1793-1794$ \\
\hline Ceres (2) & $1793-1794$ \\
\hline Warley (1) & $1793-1794$ \\
\hline Berrington & $1793-1794$ \\
\hline General Coote & $1793-1794$ \\
\hline Rodney (2) & $1793-1796$ \\
\hline Princess Amelia (3) & $1793-1796$ \\
\hline Francis (2) & $1793-1796$ \\
\hline Exeter (2) & $1793-1794,1800-1801,1803-1804,1810-1811$ \\
\hline Lord Thurlow & $1793-1794,1797-1802$ \\
\hline Lord Walsingham & $1793-1794,1797-1799$ \\
\hline Minerva (1) & $1793-1796,1799-1800$ \\
\hline Earl Of Chesterfield & $1793-1794$ \\
\hline Earl Of Wycombe & $1794-1795,1797-1799$ \\
\hline Sir Edward Hughes & $1794-1795,1797-1803$ \\
\hline Woodford (1) & $1794-1805,1807-1808,1810-1811$ \\
\hline Thetis (1) & $1794-1797$ \\
\hline Rockingham (1) & $1794-1795,1798-1802$ \\
\hline Walpole (4) & $1794-1795$ \\
\hline Phoenix (3) & $1794-1795$ \\
\hline Lord Hawkesbury & $1794-1802,1804-1806$ \\
\hline Taunton Castle & 1794-1795,1799-1800,1804-1805,1809-1810 \\
\hline Europa (2) & $1794-1795$ \\
\hline Queen (4) & $1794-1798$ \\
\hline Carnatic (2) & $1794-1795,1801-1802$ \\
\hline Princess Of Wales (3) & $1795-1797$ \\
\hline Earl Of Oxford & $1795-1796$ \\
\hline Cirencester & $1795-1796,1812-1813$ \\
\hline London (13) & $1795-1796$ \\
\hline Bellona & $1795-1798$ \\
\hline Hillsborough (2) & $1795-1798$ \\
\hline Kent (5) & $1795-1797$ \\
\hline Woodcot & $1795-1796$ \\
\hline Brunswick (1) & $1795-1797$ \\
\hline Cuffnells & $1796-1800,1802-1805,1809-1810$ \\
\hline Princess Charlotte (1) & $1796-1797$ \\
\hline Albion (2) & $1796-1798$ \\
\hline Royal Charlotte (5) & 1796-1807,1809-1815 \\
\hline Essex (4) & $1796-1798$ \\
\hline True Briton (4) & $1796-1798,1801-1802$ \\
\hline Airly Castle & 1796-1797,1804-1806 \\
\hline Walmer Castle & $1796-1798,1802-1805,1815-1816$ \\
\hline Boddam & $1796-1800$ \\
\hline Manship (1) & $1796-1800$ \\
\hline Good Hope (3) & $1796-1799$ \\
\hline Henry Addington (1) & $1796-1798$ \\
\hline Ganges (3) & $1797-1802$ \\
\hline Prince William Henry & $1797-1799$ \\
\hline Britannia (4) & $1797-1805$ \\
\hline Warley (2) & $1797-1800,1805-1809,1811-1814$ \\
\hline Hope (2) & $1797-1808,1811-1816$ \\
\hline Arniston & $1797-1798,1804-1807,1810-1811$ \\
\hline Eurydice & $1797-1799$ \\
\hline Sulivan & $1797-1798$ \\
\hline Osterley (3) & $1798-1800$ \\
\hline
\end{tabular}

Table 2. Continued.

\begin{tabular}{|c|c|}
\hline Ship Name & Years of operation \\
\hline Earl Howe & $1798-1810$ \\
\hline Lord Duncan & $1798-1806$ \\
\hline Ocean (3) & $1798-1800$ \\
\hline Tellicherry & $1798-1799$ \\
\hline Earl Cornwallis & $1798-1800$ \\
\hline Orpheus & $1798-1800$ \\
\hline Charlton & $1799-1806$ \\
\hline Asia (4) & $1799-1803$ \\
\hline Hindostan (2) & $1799-1800$ \\
\hline Duke Of Buccleugh (1) & $1799-1800$ \\
\hline Preston & $1799-1800$ \\
\hline Herculean & $1800-1801$ \\
\hline Dorsetshire & $\begin{array}{l}1800-1801,1803-1804,1806,1811- \\
1812,1814-1815,1817-1818,1820-1823\end{array}$ \\
\hline Earl Spencer (2) & $1800-1801,1803-1810$ \\
\hline Neptune (5) & $1800-1801,1804-1807,1809-1810,1812-1815$ \\
\hline Hugh Inglis & $1800-1801,1810-1812$ \\
\hline Lady Burges & $1800-1805$ \\
\hline Walthamstow & $1800-1801,1804-1805,1808-1813$ \\
\hline Lord Nelson & $1800-1801,1806-1807$ \\
\hline Ceres (4) & $1800-1805,1808-1809$ \\
\hline City Of London & $1800-1801,1803-1808,1812-1813$ \\
\hline Bengal & $1800-1802,1806-1807$ \\
\hline Canton & $1800-1805,1808-1811$ \\
\hline Georgiana (1) & $1800-1803,1805-1807$ \\
\hline Hawke (5) & $1800-1801$ \\
\hline Earl St & $1800-1801,1808-1813$ \\
\hline Henry Dundas & $1801-1802$ \\
\hline Calcutta (4) & $1801-1804$ \\
\hline Alfred (2) & $1801-1802,1807-1808,1810-1811$ \\
\hline Caledonian (2) & $1801-1803$ \\
\hline Henry Addington (2) & $1801-1802,1805-1806,1811-1812,1814-1815$ \\
\hline Walpole (5) & $1801-1802$ \\
\hline Ocean (4) & $1801-1803,1805-1806,1808-1809$ \\
\hline Northampton (2) & $1801-1805,1807-1810,1818-1819$ \\
\hline Princess Mary (2) & $1801-1805$ \\
\hline Fort William (2) & $1801-1802$ \\
\hline Monarch & $1801-1802$ \\
\hline Experiment (2) & 1801 \\
\hline Manship (2) & $1801-1803$ \\
\hline Sarah Christiana & $1801-1802$ \\
\hline Comet (2) & $1801-1803$ \\
\hline Marquis Of Ely & $1802-1805,1811-1814,1819-1820$ \\
\hline Marquis Wellesley & $1802-1803,1806-1808$ \\
\hline Castle Eden & $1802-1804$ \\
\hline Lady Jane Dundas & $1802-1807$ \\
\hline Thames (2) & $1802-1805,1809-1810,1812-1813$ \\
\hline Sir William Bensley & $1802-1811$ \\
\hline Tottenham & $1802-1803,1806-1810$ \\
\hline Travers & $1802-1806$ \\
\hline Alnwick Castle & $1802-1813,1815-1816$ \\
\hline Marchioness Of Exeter & $1802-1803,1811-1814,1816-1817$ \\
\hline Devaynes & $1802-1808,1811-1812$ \\
\hline Ann (1) & $1803-1809,1814-1815$ \\
\hline Experiment (4) & $1803-1805$ \\
\hline Cumberland & $1803-1804,1809-1810$ \\
\hline Warren Hastings (2) & $1803-1804$ \\
\hline Harriet (3) & $1803-1811$ \\
\hline Elphinstone & $1803-1811$ \\
\hline Tigris (2) & $1803-1805,1810-1815$ \\
\hline Marquis Cornwallis (2) & 1803 \\
\hline Windham (2) & $1803-1806,1816-1817$ \\
\hline Europe (2) & $1803-1807$ \\
\hline Euphrates & $1803-1805$ \\
\hline General Stuart & $1803-1804,1807,1811-1814$ \\
\hline Essex (5) & $1803-1805,1808-1809,1819-1820$ \\
\hline Carmarthen & $1803-1818$ \\
\hline Union (4) & $1803-1804,1808-1812,1815-1818$ \\
\hline
\end{tabular}


Table 3. Ships from which observations were taken ( 2 of 2 - starting dates 1803 to 1833 ).

\begin{tabular}{|c|c|}
\hline Ship Name & Years of operation \\
\hline Ocean (5) & $1803-1805$ \\
\hline Lord Melville (1) & $1803-1808,1811-1816$ \\
\hline Dover Castle & $1804-1805,1809-1810$ \\
\hline Indus & $1804-1805,1810-1815$ \\
\hline Alexander (3) & $1804-1809,1814$ \\
\hline Lord Eldon & $1804-1814$ \\
\hline Waller & 1804 \\
\hline Winchelsea (3) & $\begin{array}{l}1804-1807,1810-1815,1817- \\
1818,1820-1823,1831-1832\end{array}$ \\
\hline Ocean (6) & $1804-1814$ \\
\hline Huddart & 1804-1805,1808-1809,1815-1816 \\
\hline United Kingdom & $1804-1805,1807-1808$ \\
\hline Bombay Castle & $1805-1806$ \\
\hline Surrey (1) & $1805-1810$ \\
\hline Northumberland (5) & $1805-1818$ \\
\hline Royal George (4) & $1805-1811,1814-1818$ \\
\hline Sir William Pultney & $1805-1807,1815-1816$ \\
\hline Streatham (4) & $1805-1814,1817-1818$ \\
\hline Glory & $1805-1807$ \\
\hline William Pitt (2) & $1805-1807,1810-1820$ \\
\hline Phoenix (5) & $1805-1809,1816-1819$ \\
\hline Wexford & $1805-1817$ \\
\hline David Scott (2) & 1806-1807,1812-1813,1815-1816 \\
\hline Glatton (4) & 1806-1807,1809-1810,1812-1815 \\
\hline Sir Stephen Lushington & $1806-1811$ \\
\hline Regent & $1807,1816-1819,1822$ \\
\hline Lady Castlereagh & $1807-1817$ \\
\hline Admiral Gardner & $1807-1808$ \\
\hline Union (5) & $1807-1808,1813-1814$ \\
\hline Lord Keith & 1808-1811,1814-1819 \\
\hline Princess Amelia (4) & $1809-1825$ \\
\hline Thomas Grenville & $1809-1832$ \\
\hline Warren Hastings (3) & $\begin{array}{l}1809-1810,1814-1821,1825- \\
1828,1831-1834\end{array}$ \\
\hline Coutts & $1809-1810,1812-1815$ \\
\hline Lady Lushington & $1809-1814,1818-1819$ \\
\hline Farlie & $1809-1814,1818-1819$ \\
\hline Charles Grant & 1810-1816,1819-1830,1832-1833 \\
\hline Surat Castle (2) & $1810-1815$ \\
\hline Lady Carrington & $1810,1812-1817$ \\
\hline Midas & $1810-1811$ \\
\hline Warren Hastings (5) & $\begin{array}{l}1811-1812,1815-1816,1819- \\
1820,1823-1826\end{array}$ \\
\hline Carnatic (3) & $1811-1820$ \\
\hline John Palmer & 1811 \\
\hline Cambridge & $1811-1812,1825-1827$ \\
\hline Scaleby Castle & $1811-1812,1814-1828,1831-1834$ \\
\hline William Pitt (3) & $1811-1812$ \\
\hline Harleston & $1811-1812$ \\
\hline Moffat & $1811-1812,1818-1819$ \\
\hline Rose (4) & $1811-1822,1824-1827,1833-1834$ \\
\hline General Harris & $1812-1831$ \\
\hline Broxbornebury & $1812-1813,1825-1828$ \\
\hline Asia (6) & $1812-1826,1832-1833$ \\
\hline Marquis Of Huntley & $1812-1813,1818-1823,1831-1834$ \\
\hline Perseverance (2) & $1812-1814,1818-1819$ \\
\hline Marquis Camden & $1812-1814,1821-1829,1832-1833$ \\
\hline Juliana & $1812-1813$ \\
\hline Astell & $\begin{array}{l}1812-1813,1818-1821,1824- \\
1825,1830-1831\end{array}$ \\
\hline Princess Charlotte Of Wales & $1812-1822,1825-1828$ \\
\hline Coldstream & $1812-1813,1816-1817,1822-1823$ \\
\hline Cabalva & $1812-1817$ \\
\hline David Scott (1) & $1813-1814$ \\
\hline Marquis Of Wellington (1) & $1813-1822,1827,1829-1830$ \\
\hline Atlas (4) & $1813-1830$ \\
\hline
\end{tabular}

Table 3. Contined.

\begin{tabular}{|c|c|}
\hline Ship Name & Years of operation \\
\hline Lowther Castle & $1813-1828,1831-1834$ \\
\hline Bombay & $\begin{array}{l}1814-1815,1817-1822,1825- \\
1828,1831-1834\end{array}$ \\
\hline Prince Regent & $1814-1815,1818-1829,1833-1834$ \\
\hline Lady Melville & $1814-1821,1824-1827,1829-1834$ \\
\hline Minerva (7) & $1815-1822,1825-1832$ \\
\hline Surrey (2) & 1815 \\
\hline General Kyd & $1815-1816,1823-1832$ \\
\hline James Sibbald & $1815-1816,1826-1829$ \\
\hline Sovereign (2) & $1816-1817$ \\
\hline Northampton (3) & 1816 \\
\hline Fort William (3) & $1816-1817$ \\
\hline Mangles & $1816-1819$ \\
\hline Buckinghamshire & $1816-1824$ \\
\hline Providence (1) & $1816-1817$ \\
\hline Larkins (1) & $1816-1817$ \\
\hline Earl Of Balcarras & $1816-1833$ \\
\hline Vansittart (4) & $1817-1824,1827-1834$ \\
\hline Lord Castlereagh (1) & $1817-1820$ \\
\hline Waterloo (1) & $1817-1832$ \\
\hline Bridgewater (5) & $1817-1830$ \\
\hline Herefordshire & $1817-1818,1821-1826,1829-1834$ \\
\hline Barkworth & $1817-1818$ \\
\hline Castle Huntley & $\begin{array}{l}1818-1821,1824-1825,1828- \\
1831,1833-1834\end{array}$ \\
\hline General Hewett & $1818-1825$ \\
\hline London (14) & $1818-1823,1826-1833$ \\
\hline Canning & $1818-1832$ \\
\hline Duke Of York (2) & $1818-1826,1829-1830$ \\
\hline Dunira & $1818-1819,1822-1823,1830-1833$ \\
\hline Thomas Coutts & $1818-1825,1828-1833$ \\
\hline Henry Porcher & $1818-1819$ \\
\hline Matilda & $1819-1820$ \\
\hline Kellie Castle & 1819-1830,1833-1834 \\
\hline Inglis & 1819-1832 \\
\hline Thames (5) & $1819-1821,1824-1827,1829-1834$ \\
\hline Cornwall & $1819-1820,1826$ \\
\hline Windsor (2) & $1819-1820,1825-1828,1832-1833$ \\
\hline Marchioness Of Ely & $1820-1821,1826-1829$ \\
\hline Orwell & $1820-1831$ \\
\hline Kent (7) & $1821-1824$ \\
\hline Royal George (5) & $1821-1824$ \\
\hline Farquharson & $1821-1828,1831-1834$ \\
\hline William Fairlie & $1822-1833$ \\
\hline Berwickshire & $1822-1833$ \\
\hline Sir David Scott & $1822-1825,1830-1833$ \\
\hline Duchess Of Athol & $1822-1826,1828-1833$ \\
\hline Repulse & $1823-1830$ \\
\hline Claudine & $1824-1825$ \\
\hline Macqueen & $1824-1825,1830-1833$ \\
\hline Java & 1825 \\
\hline Clyde (2) & $1825-1826$ \\
\hline George The Fourth & $1826-1833$ \\
\hline Edinburgh & $1826-1831$ \\
\hline Reliance & $1828-1833$ \\
\hline Abercrombie Robinson & $1828-1833$ \\
\hline Maitland & $1828-1829$ \\
\hline Asia (10) & $1829-1830$ \\
\hline Susan (2) & $1830-1831$ \\
\hline Marquis Of Hastings & $1830-1831$ \\
\hline Lord Lowther & $1830-1833$ \\
\hline Duke Of Sussex & $1831-1832$ \\
\hline Duke Of Buccleugh (2) & $1831-1832$ \\
\hline Bencoolen & $1832-1833$ \\
\hline Sherborne (2) & $1833-1834$ \\
\hline
\end{tabular}




\section{Constraining proxy reconstructions and GCM simulations}

The biases in the observed air temperatures mean that it is difficult to compare temperatures in the early nineteenth century with present-day values, but the observational method and ship routes were constant over the period covered by the EEIC observations so they can be used directly to look at temperature variations over the period 1795-1833 (when there were enough ships contributing to give reliable results). Extracting a set of pseudo-observations from each GCM run, by sampling from the model output fields at the date and location of each observation allows a direct comparison between observations and simulations (Fig. 9: upper panel). It is clear that the observational coverage is sufficient to show the effect of the volcanoes in the simulations, and it is also clear that the observations support those simulations with a small temperature response to the Tambora and 1809 eruptions. Much of the variation between simulations is a reflection of the uncertain forcing produced by the eruptions (Wagner and Zorita, 2005; Schmidt et al., 2011), so this says little about the accuracy of any GCM, but it does demonstrate that the large volcanic response present in several simulations did not occur.

Comparison with the proxies is more complicated, as they do not usually provide field reconstructions - just time series for the entire Northern Hemisphere (NH). However, comparing the GCM results subsampled to the coverage of the observations with their $\mathrm{NH}$ averages (Fig. 9: inset) indicate that the $\mathrm{NH}$ temperature anomalies are linearly related to the observational anomalies $\Delta T_{\mathrm{NH}} \approx \Delta T_{\text {obs }} \times 1.2$, and Fig. 9 (lower panel) compares the proxy reconstructions to the observational series scaled by this factor.

With the exception of the glacier based reconstruction (O2005), which has (unsurprisingly) too little variance on these short time scales, the agreement between the proxy reconstructions and the observations is good. It is not easy to say which of the proxy series is the best, but as a group they match the observations well. As this comparison is for a period outside that used to calibrate the proxies (both in time and temperature), the observations form a validation for the proxy reconstructions - demonstrating that the proxies can be used to extrapolate back into the past and into different climates, with success.

\section{Conclusions}

The records of the English East India Company (EEIC), archived in the British Library, offer a remarkable new insight into the weather and climate of the late eighteenth and early nineteenth centuries. Their archives include 891 ships' logbooks containing daily temperature and pressure measurements, and wind-speed estimates, each covering a voyage from England to India or China and back. The 273000 new weather observations extracted from those logs provide material for detailed reconstructions of the weather and climate between 1789 and 1834 and offer new insights into pre-industrial climate variability. For all three meteorological variables studied (temperature, pressure and wind) it is clear that the data can be used for investigating variability over the period of measurement, though comparison with measurements made decades or centuries later will require close attention to observational biases.

The observations demonstrate that the large-scale temperature change, over the Atlantic and Indian Oceans, associated with the two big tropical volcanic eruptions in 1809 and 1815 was modest (perhaps $0.5^{\circ} \mathrm{C}$ ). Some of the GCM simulations in the CMIP5 ensemble show much larger volcanic effects than this - such simulations are unlikely to be accurate in this respect. Recent annually-resolved proxy reconstructions of Northern Hemisphere temperature show a varied but similarly modest volcanic response (about $0.2-0.7^{\circ} \mathrm{C}$ ); the new observations therfore provide an out-of-sample validation for the proxy reconstructions - supporting their use for longerterm climate reconstructions.

\section{Supplementary material related to this article is available online at: http://www.clim-past.net/8/1551/ 2012/cp-8-1551-2012-supplement.zip.}

Acknowledgement. This work was made possible by the UK Department for Environment, Food and Rural Affairs (Defra), which paid for the investigation and photography of the original log-books; and by the US Climate Database Modernisation Program (CDMP) which transcribed the weather records from the photographs. PB was also supported by the Joint DECC and Defra Integrated Climate Programme, DECC/Defra (GA01101).

We acknowledge the World Climate Research Programme's Working Group on Coupled Modelling, which is responsible for CMIP, and we thank the climate modelling groups (listed in Table 1) for producing and making available their model output. For CMIP the US Department of Energy's Program for Climate Model Diagnosis and Intercomparison provides coordinating support and led development of software infrastructure in partnership with the Global Organization for Earth System Science Portals.

Edited by: B. Vinther

\section{References}

Alcoforado, M. J., Vaquero, J. M., Trigo, R. M., and Taborda, J. P.: Early Portuguese meteorological measurements (18th century), Clim. Past, 8, 353-371, doi:10.5194/cp-8-353-2012, 2012.

Allan, R. J. and Ansell, T. J.: A new globally complete monthly historical gridded mean sea level pressure data set (HadSLP2): 1850-2003, J. Climate, 19, 5816-5842, 2006.

Ansell, T. J., Jones, P. D., Allan, R. J., Lister, D., Parker, D. E., Brunet, M., Moberg, A., Jacobeit, J., Brohan, P., Rayner, N. A., 
Aguilar, E., Alexandersson, H., Barriendos, M., Brandsma, T., Cox, N. J., Della-Marta, P. M., Drebs, A., Founda, D., Gerstengarbe, F., Hickey, K., Jonsson, T., Luterbacher, J., Nordli, O., Oesterle, H., Petrakis, M., Philipp, A., Rodwell, M. J., Saladie, O., Sigro, J., Slonosky, V., Srnec, L., Swail, V., Garcia-Suarez, A. M., Tuomenvirta, H., Wang, X., Wanner, H., Werner, P., Wheeler, D., and Xoplaki, E.: Daily mean sea level pressure reconstructions for the European-North Atlantic Region for the period 1850-2003, J. Climate, 19, 2717-2742, doi:10.1175/JCLI3775.1, 2006.

Berry, D. I. and Kent, E. C.: The effect of instrument exposure on marine air temperatures: an assessment using VOSClim data, Int. J. Climatol., 25, 1007-22, doi:10.1002/joc.1178, 2005.

Briffa, K. R.: Annual climate variability in the Holocene: interpreting the message of ancient trees, Quaternary Sci. Rev., 19, 87$105,2000$.

Briffa, K. R., Osborn, T. J., Schweingruber, F. H., Harris, I. C., and Jones, P. D.: Low-frequency temperature variations from a northern tree ring density network, J. Geophys. Res., 106, 2929-2941, 2001.

Briffa, K. R., Osborn, T. J., and Schweingruber, F. H.: Large-scale temperature inferences from tree rings: a review, Global Planet. Change, 40, 11-26, 2004.

Brohan, P., Kennedy, J., Harris, I., Tett, S. F. B., and Jones, P. D.: Uncertainty Estimates in Regional and Global Observed Temperature Changes: a new dataset from 1850, J. Geophys. Res., 111, D12106, doi:10.1029/2005JD006548, 2006.

Brohan, P., Allan, R., Freeman, J. E., Waple, A., Wheeler, D., Wilkinson, C., and Woodruff, S.: Marine observations of old weather, B. Am. Meteorol. Soc., 90, 219-230, doi:10.1175/2008BAMS2522.1, 2009.

Brohan, P., Ward, C., Willets, G., Wilkinson, C., Allan, R., and Wheeler, D.: Arctic marine climate of the early nineteenth century, Clim. Past, 6, 315-324, doi:10.5194/cp-6-315-2010, 2010.

Camuffo, D. and Bertolin, C.: The earliest temperature observations in the world: the Medici Network (1654-1670), Clim. Change, 111, 335-363, doi:10.1007/s10584-011-0142-5, 2011.

Chenoweth, M.: Ship's Logbooks and "The Year Without an Summer", B. Am. Meteorol. Soc., 77, 2077-2094, 1996.

Chenoweth, M.: A new methodology for Homogenization of 19th century marine air temperature data, J. Geophys. Res., 105, 29145-29154, 2000.

CLIWOC: CLIWOC multilingual dictionary: an English-SpanishDutch-French dictionary of wind force terms used by mariners from 1750 to 1850 , KNMI publication 205, De Bildt, The Netherlands, 2003.

Cook, E. R., Esper, J., and D'Arrigo, R. D.: Extra-tropical Northern Hemisphere land temperature variability over the past 1000 years, Quaternary Sci. Rev., 23, 2063-2074, 2004.

Dalrymple, A.: Journal of a voyage to the East Indies in the ship Grenville, Captain Burnet Abercrombie, in the year 1775, Philos. T. R. Soc. Lond., 68, 389-418, 1778.

D'Arrigo, R. D., Wilson, R., and Jacoby, G.: On the long-term context for late twentieth century warming, J. Geophys. Res., 11, D03103, doi:10.1029/2005JD006352, 2006.

Esper, J., Cook, E. R., and Schweingruber, F. H.: Low-Frequency Signals in Long Tree-Ring Chronologies for Reconstructing Past Temperature Variability, Science, 295, 2250-2253, 2002.
Farrington, A.: A Catalogue of East India Company Ships, Journals and Logs 1600-1834, British Library, 1999.

Farrington, A., Lubker, S., Radok, U., and Woodruff, S.: South Atlantic winds and weather during and following the Little Ice Age - a pilot study of English East India Company Ship Logs, Meteorol. Atmos. Phys., 67, 253-257, 1998.

Foster, W.: The Voyage of Sir Henry Middleton to the Moluccas, 1604-1606, Hakluyt Society, 2010.

Frank, D., Esper, J., Zorita, E., and Wilson, R.: A noodle, hockey stick, and spaghetti plate: a perspective on highresolution paleoclimatology, WIREs Climate Change, 1, 507-16, doi:10.1002/wcc.53, 2010.

Gent, P. R., Danabasoglu, G., Donner, L. J., Holland, M. M., Hunke, E. C., Jayne, S. R., Lawrence, D. M., Neale, R. B., Rasch, P. J., Vertenstein, M., Worley, P. H., Yang, Z.-L., and Zhang, M.: The Community Climate System Model Version 4, J. Climate, 24, 4973-4991, doi:10.1175/2011JCLI4083.1, 2011.

Hegerl, G. C., Crowley, T. J., Hyde, W. T., and Frame, D. J.: Climate sensitivity constrained by temperature reconstructions over the past seven centuries, Nature, 440, 1029-1032, 2006.

Jansen, E., Overpeck, J., Briffa, K. R., Duplessy, J. C., Joos, F., Masson-Delmotte, V., Olago, D., Otto-Bliesner, B., Peltier, W. R., Rahmstorf, S., Ramesh, R., Raynaud, D., Rind, D., Solomina, O., Villalba, R., and Zhang, D.: PalaeoClimate, chap. 6 of Climate Change 2007: The Physical Science Basis. Contribution of Working Group I to the Fourth Assessment Report of the Intergovernmental Panel on Climate Change, edited by: Solomon, S., Qin, D., Manning, M., Marquis, M., Averyt, K. B., Tignor, M., Miller, H. L., and Chen, Z., 433-497, Cambridge University Press, 2007.

Jones, P. D. and Mann, M. E.: Climate over past millennia, Rev. Geophys., 42, RG2002, doi:10.1029/2003RG000143, 2004.

Jones, P. D., Briffa, K., Barnett, T. P., and Tett, S. F. B.: Highresolution palaeoclimatic records for the last millennium: interpretation, integration and comparison with General Circulation Model control run temperatures, Holocene, 8, 455-471, 1998.

Jones, P. D., Briffa, K. R., and Osborn, T. J.: The evolution of climate over the last millennium, Science, 292, 662-667, 2001.

Jones, P. D., Briffa, K. R., Osborn, T. J., Lough, J. M., van Ommen, T. D., Vinther, B. M., Luterbacher, J., Wahl, E. R., Zwiers, F. W., Mann, M. E., Schmidt, G. A., Ammann, C. M., Buckley, B. M., Cobb, K. M., Esper, J., Goose, H., Graham, N., Jansen, E., Kiefer, T., Kull, C., Kuttel, M., Mosley-Thompson, E., Overpeck, J. T., Riedwyl, N., Schulz, M., Tudhope, A. W., Villalba, R., Wanner, H., Wolff, E., and Xoplaki, E.: High-resolution palaeoclimatology of the last millennium: a review of current status and future prospects, Holocene, 19, 3-49, doi:10.1177/0959683608098952, 2009.

Mann, M. E. and Jones, P. D.: Global surface temperatures over the past two millennia, Geophys. Res. Lett., 30, 1820, doi:10.1029/2003GL017814, 2003.

Mann, M. E., Bradley, R. S., and Hughes, M. K.: Northern Hemisphere temperatures during the past millennium: inferences, uncertainties, and limitations, Geophys. Res. Lett., 26, 759-762, 1999.

Mann, M. E., Fuentes, J. D., and Rutherford, S.: Underestimation of volcanic cooling in tree-ring-based reconstructions of hemispheric temperatures, Nat. Geosci., 5, 202-205, doi:10.1038/ngeo1394, 2012. 
Marsland, S. J., Haak, H., Jungclaus, J. H., Latif, M., and Roeske, F.: The Max-Planck-Institute global ocean/sea ice model with orthogonal curvilinear coordinates, Ocean Modell., 5, 91-127, 2003.

Middleton, W. E. K.: The history of the barometer, Baros Books, 1964.

Moberg, A., Sonechkin, D. M., Holmgren, J. K., Datsenko, N. M., and Karlen, W.: Highly variable Northern Hemisphere temperatures reconstructed from low- and high-resolution proxy data, Nature, 433, 613-617, 2005.

Oerlemans, J.: Extracting a Climate Signal from 169 Glacier Records, Science, 308, 675-677, doi:10.1126/science.1107046, 2005.

Raddatz, T. J., Reick, C. H., Knorr, W., Kattge, J., Roeckner, E., Schnur, R., Schnitzler, K. G., Wetzel, P., and Jungclaus, J.: Will the tropical land biosphere dominate the climate-carbon cycle feedback during the twenty-first century?, Clim. Dynam., 29, 565-574, doi:10.1007/s00382-007-0247-8, 2007.

Rayner, N. A., Parker, D. E., Horton, E. B., Folland, C. K., Alexander, L. V., Rowell, D. P., Kent, E. C., and Kaplan, A.: Global analyses of SST, sea ice and night marine air temperature since the late nineteenth century, J. Geophys. Res., 108, 4407, doi:10.1029/2002JD002670, 2003.

Rutherford, S., Mann, M. E., Osborn, T. J., Briffa, K. R., Jones, P. D., Bradley, R. S., and Hughes, M. K.: Proxy-Based Northern Hemisphere Surface Temperature Reconstructions: Sensitivity to Method, Predictor Network, Target Season, and Target Domain, J. Climate, 18, 2308-2329, doi:10.1175/JCLI3351.1, 2005.

Schmidt, G. A., Ruedy, R., Hansen, J. E., Aleinov, I., Bell, N., Bauer, M., Baue, S., Cairns, B., Canut, V., Cheng, Y., Genio, A. D., Faluvegi, G., Friend, A. D., Hall, T. M., Hu, Y., Kelley, M., Kiang, N. Y., Koch, D., Lacis, A. A., Lerner, J., Lo, K. K., Miller, R. L., Nazarenko, L., Oinas, V., Perlwitz, J., Perlwitz, J., Rind, D., Romanou, A., Russell, G. L., Sato, M., Shindell, D. T., Stone, P. H., Sun, S., Tausnev, N., Thresher, D., and Yao, M.-S.: Present day atmospheric simulations using GISS Model E: Comparison to in-situ, satellite and reanalysis data, J. Climate, 19, 153-192, 2006.

Schmidt, G. A., Jungclaus, J. H., Ammann, C. M., Bard, E., Braconnot, P., Crowley, T. J., Delaygue, G., Joos, F., Krivova, N. A., Muscheler, R., Otto-Bliesner, B. L., Pongratz, J., Shindell, D. T., Solanki, S. K., Steinhilber, F., and Vieira, L. E. A.: Climate forcing reconstructions for use in PMIP simulations of the last millennium (v1.0), Geosci. Model Devel., 4, 33-45, doi:10.5194/gmd-4-33-2011, 2011.
Taylor, K. E., Stouffer, R. J., and Meehl, G. A.: An Overview of CMIP5 and the Experiment Design, B. Am. Meteorol. Soc., 93, 485-498, doi:10.1175/BAMS-D-11-00094.1, 2012.

Uppala, S. M., Kållberg, P. W., Simmons, A. J., Andrae, U., da Costa Bechtold, V., Fiorino, M., Gibson, J. K., Haseler, J., Hernandez, A., Kelly, G. A., Li, X., Onogi, K., Saarinen, S., Sokka, N., Allan, R. P., Andersson, E., Arpe, K., Balmaseda, M. A., Beljaars, A. C. M., van de Berg, L., Bidlot, J., Bormann, N., Caires, S., Chevallier, F., Dethof, A., Dragosavac, M., Fisher, M., Fuentes, M., Hagemann, S., Hólm, E., Hoskins, B. J., Isaksen, L., Janssen, P. A. E. M., Jenne, R., McNally, A. P., Mahfouf, J.-F., Morcrette, J.-J., Rayner, N. A., Saunders, R. W., Simon, P., Sterl, A., Trenberth, K. E., Untch, A., Vasiljevic, D., Viterbo, P., and Woollen, J.: The ERA-40 re-analysis., Q. J. Roy. Meteorol. Soc., 131, 2961-3012, doi:10.1256/qj.04.176, 2005.

Wagner, S. and Zorita, E.: The influence of volcanic, solar and CO2 forcing on the temperatures in the Dalton Minimum (1790-1830): a model study, Clim. Dynam., 25, 205-218, doi:10.1007/s00382-005-0029-0, 2005.

Watanabe, S., Hajima, T., Sudo, K., Nagashima, T., Takemura, T., Okajima, H., Nozawa, T., Kawase, H., Abe, M., Yokohata, T., Ise, T., Sato, H., Kato, E., Takata, K., Emori, S., and Kawamiya, M.: MIROC-ESM 2010: model description and basic results of CMIP5-20c3m experiments, Geosci. Model Devel., 4, 845-872, doi:10.5194/gmd-4-845-2011, 2010.

Wheeler, D., Herrera, R. G., Koek, F., Wilkinson, C., Konnen, G., del Rosario Prieto, M., Jones, P. D., and Casale, R.: CLIWOC, Climatological database for the world's oceans, European Commission, 2006.

Woodruff, S.: Archival of data other than in IMMT format: The International Maritime Meteorological Archive (IMMA) format, in Expert Team on Marine Climatology, Second Session, Geneva, Switzerland, 26-27 March 2007 (Annex VII), JCOMM Technical Report, No. 40, 68-101, 2007.

Wu, T., Li, W., Ji, J., Xin, X., Li, L., Wang, Z., Zhang, Y., Li, J., Zhang, F., Wei, M., Shi, X., Wu, F., Zhang, L., Chu, M., Jie, W., Liu, Y., Wang, F., Liu, X., Li, Q., Dong, M., Liu, Q., and Zhang, J.: Global carbon budgets simulated by the Beijing Climate Center Climate System Model for the last century, J. Climate, submitted, 2012.

Zhou, T., Wu, B., Wen, X., Li, L., and Wang, B.: A Fast Version of LASG/IAP Climate System Model and Its 1000-year Control Integration, Adv. Atmos. Sci., 25, 655-672, 2008. 